\title{
Intraorbital foreign bodies: Clinical features and outcomes of surgical removal
}

\author{
Ayşe Dolar Bilge, M.D., Hakan Yılmaz, M.D., Bülent Yazıcı, M.D., Faisal Naqadan, M.D.
}

Department of Ophthalmology, Uludağ University Faculty of Medicine, Bursa-Turkey

\begin{abstract}
BACKGROUND: The present study is an evaluation of clinical features and management outcomes of patients operated on for intraorbital foreign bodies (FBs).

METHODS: Medical records of 24 patients who underwent surgery for intraorbital FBs within a 10-year period were reviewed.

RESULTS: Twenty patients (83\%) were male and 4 (17\%) were female (mean age: 28 years; range: 4-69 years). Ten patients (42\%) presented within 48 hours of injury, 7 (29\%) within 3 days to I month, and 7 (29\%) more than I month after injury. FBs were inorganic in 19 patients $(79 \%)$, and organic in $5(21 \%)$. Major ocular morbidities were orbital cellulitis $(n=5)$, traumatic optic neuropathy ( $n=3)$, globe perforation $(n=2)$, and rupture of rectus muscle $(n=2)$. FBs could be completely removed in all cases. Mean follow-up time was 26 months (range: I month-10 years).
\end{abstract}

CONCLUSION: Intraorbital FBs are usually inorganic and metallic, and occur more frequently in young males. Orbital cellulitis, considered typical for organic FBs, may also occur with metallic that perforate lacrimal sac or paranasal sinuses. With appropriate caution, intraorbital FBs can be removed safely with current orbitotomy techniques.

Keywords: Intraorbital foreign body; orbitotomy; surgical management.

\section{INTRODUCTION}

Penetration of orbit by foreign body $(\mathrm{FB})$ is a relatively rare type of injury. FBs may be organic or inorganic, and may remain asymptomatic in orbit or may lead to serious morbidities such as cellulitis, optic neuropathy and ocular dismotility. [1] Asymptomatic inorganic FBs may be followed-up without surgical removal. When deciding to perform surgery, potential complications of surgical removal are also considered, as well as composition and possible effects of intraorbital FB. ${ }^{[2]}$ In this report, clinical features and management outcomes of group of patients who underwent orbitotomy for FB removal were reviewed.

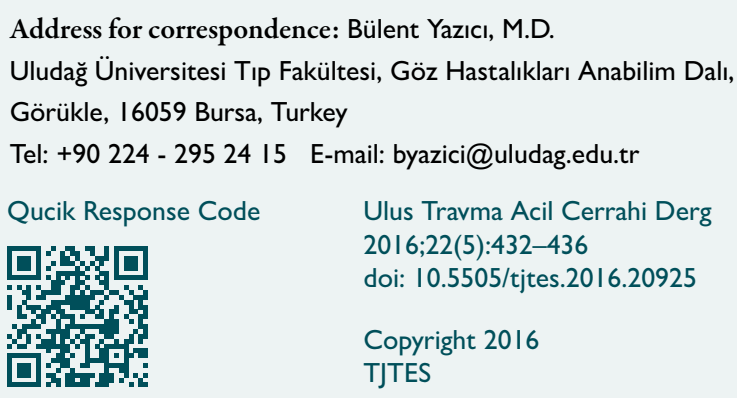

\section{MATERIALS AND METHODS}

Medical records of 24 patients operated on for intraorbital FB between January 2004 and April 2014 were reviewed. The data analyzed included age, gender, time between injury and surgery, features of FB, presence of globe perforation, visual acuity, surgical approach, management outcome, complications and follow-up duration. Patients with intraorbital FB in whom the surgical removal was not indicated or those in whom FBs were located superficially under eyelid skin or conjunctiva were excluded.

Patients all underwent complete eye examination. Orbital imaging was performed to determine location and other features of FB. Computed tomography (CT) was used for injuries with metallic FBs, while magnetic resonance imaging (MRI) was preferred for organic FBs. Surgical approach for FB removal was depended on location of FB in orbit. All operations were performed by the same surgeon.

\section{RESULTS}

Study included 20 (83\%) male and 4 (17\%) female patients, ranging in age from 4 to 69 years (mean and median ages: 28 and 23 years, respectively). Time between injury and presentation varied from hours to 5 years. Ten patients (42\%) pre- 
sented within 48 hours of injury, 2 (8\%) patients presented within 3 to 7 days, 5 (21\%) between 8 days and I month, and 7 (29\%) presented more than I month after injury. Three patients had previously undergone unsuccessful surgery for FB removal at other medical facilities.

Ten right (42\%) and 14 (58\%) left orbits were involved. Intraorbital FBs were inorganic and organic in 19 (79\%) and $5(21 \%)$ patients, respectively. Inorganic FBs were metallic $(n=13)$, glass $(n=5)$, and plastic $(n=1)$. Metallic FBs were metal fragments $(n=8)$, shotgun pellets $(n=2$ patients), nail $(n=1)$, shrapnel fragment $(n=l)$ and bullet $(n=I$ patient). Organic FBs were wood.

Associated findings were orbital cellulitis $(n=5)$, chronic cutaneous fistula $(n=3)$, optic neuropathy $(n=3)$, rupture of extraocular muscle $(n=2)$, globe perforation $(n=2)$, and large eyelid defect, intracranial penetration, intraorbital arteriovenous fistula, and chorioretinal atrophy in I patient each (Fig.
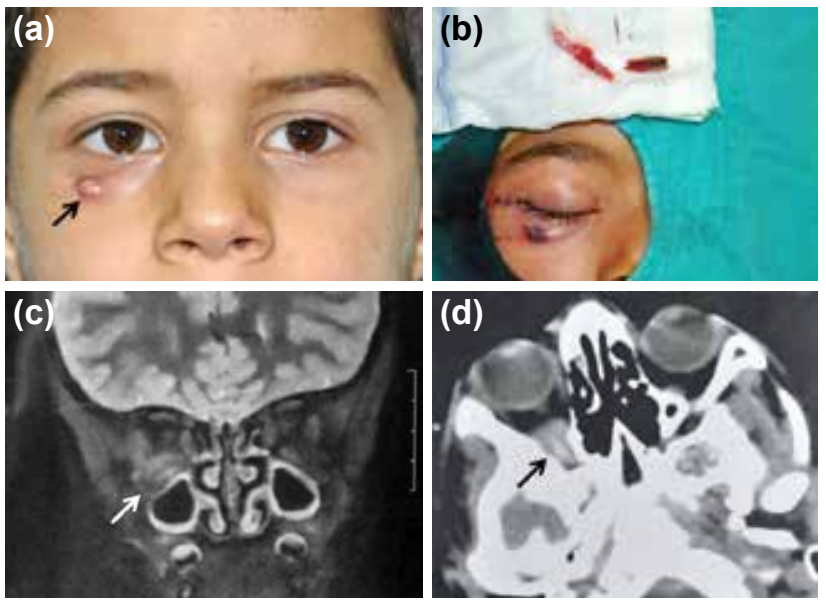

Figure 1. (a) A patient with right inferior orbital wooden foreign body that penetrated orbit 1 year previously. (b) FB was removed in several pieces. (c, d) Orbital MRI and CT images show FB (arrows) extending to orbital apex.
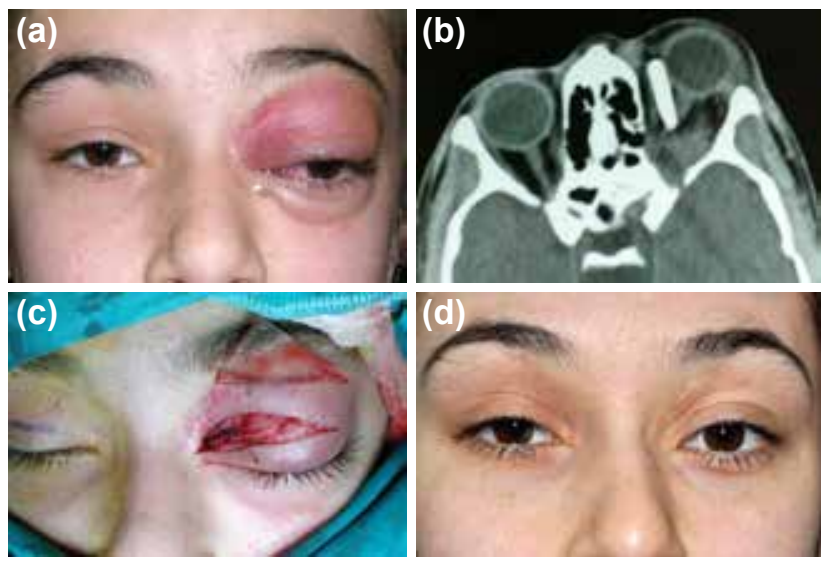

Figure 2. (a) Patient in whom inorganic FB (glass) caused arteriovenous fistula in left orbit. (b, c) Axial CT imaging and intraoperative appearance of FB. (d) Appearance of patient 10 years after surgery.
I, 2). Preoperative visual acuity was no light perception in 2 patients, and less than $20 / 200$ in 3 patients.

Surgeries were performed under general and local anesthesia in 20 and 4 patients, respectively. FBs were reached through transcutaneous incisional approach in 18 patients, transconjunctival incision in 6 patients, and were removed successfully in all cases (Fig. 3). Reconstructive procedures, performed during same surgery, included extraocular muscle rupture repair and orbital wall repair in 2 patients, and dural defect repair, eyelid skin grafting, and external dacryocystorhinostomy in I patient (Fig. 4, 5). After removal of FB, extraocular motility improved significantly in eyes with restrictive myopathy at presentation (Fig. 4-7). No patient had any additional impairment of visual acuity after surgery. Three patients who presented with optic neuropathy had no visual improvement after FB removal. No patient had surgical complications or required secondary surgery. Postoperative follow-up ranged from I month to 10 years (mean: 26 months).
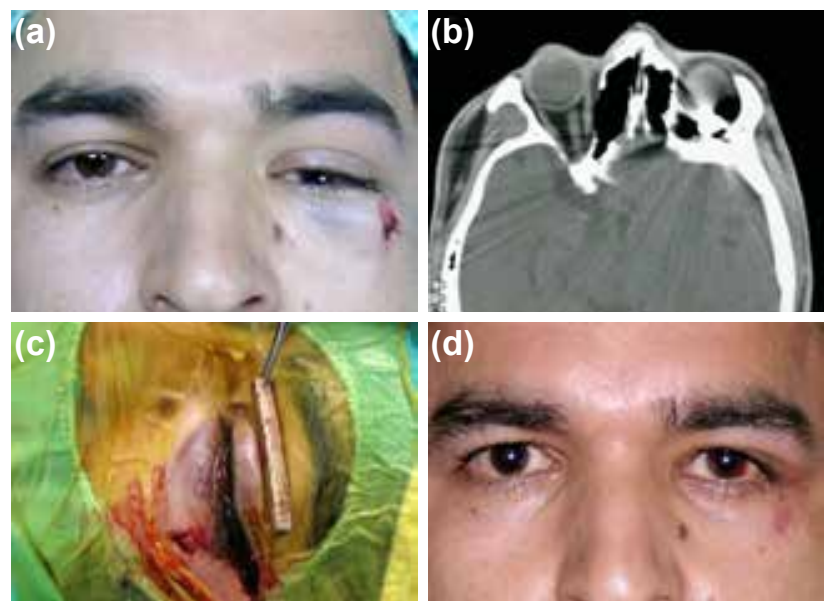

Figure 3. (a) Patient with metallic FB at presentation. (b) Axial CT image shows distal portion of FB. (c) Lesion was removed through transconjunctival approach. (d) Early postoperative image of patient.
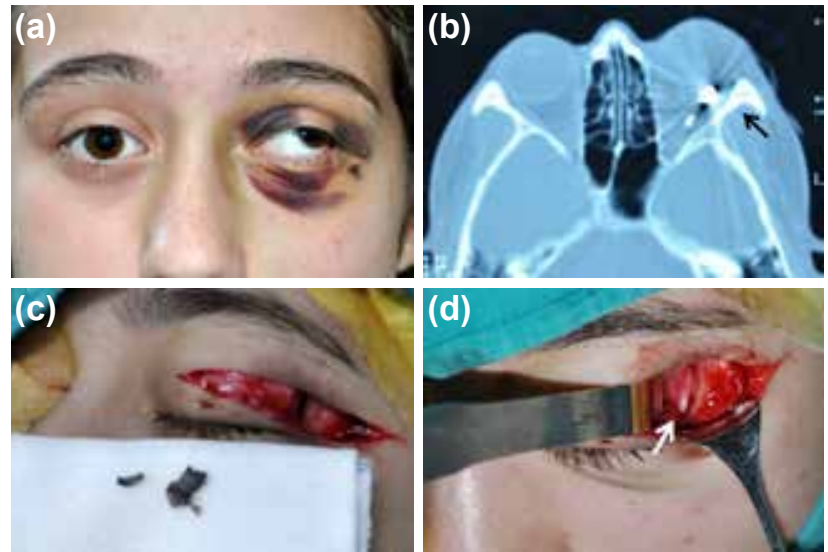

Figure 4. (a) Patient with left optic neuropathy and exotropia after shotgun pellet injury 12 days earlier. (b) Axial CT image shows FB. (c, d) Orbital pellet removed, lateral orbital defect reconstructed using polyethylene plate, and lateral rectus muscle repaired. 

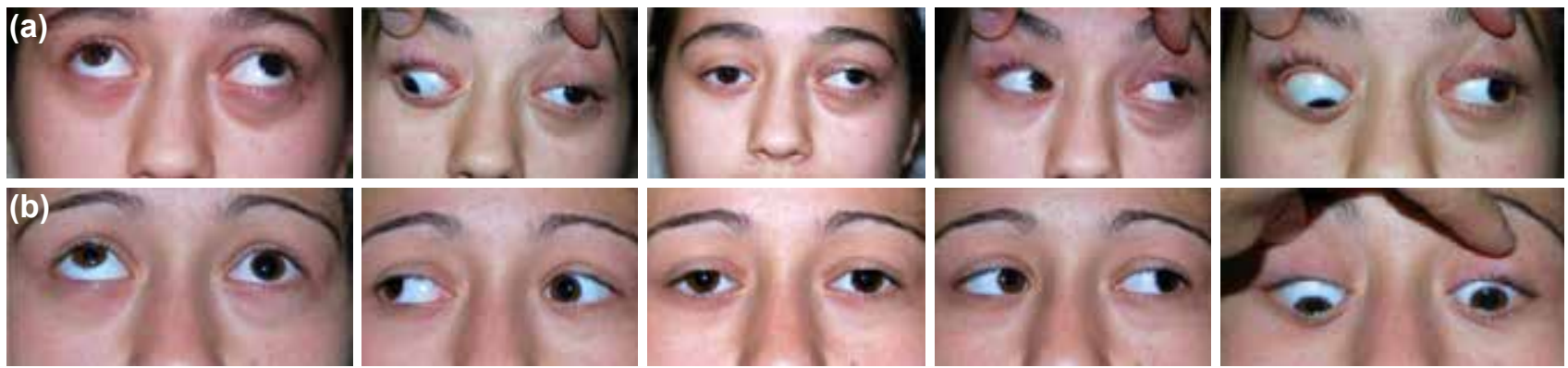

Figure 5. Eye movement of patient in Figure 4 before (a) and after (b) orbital FB removal.
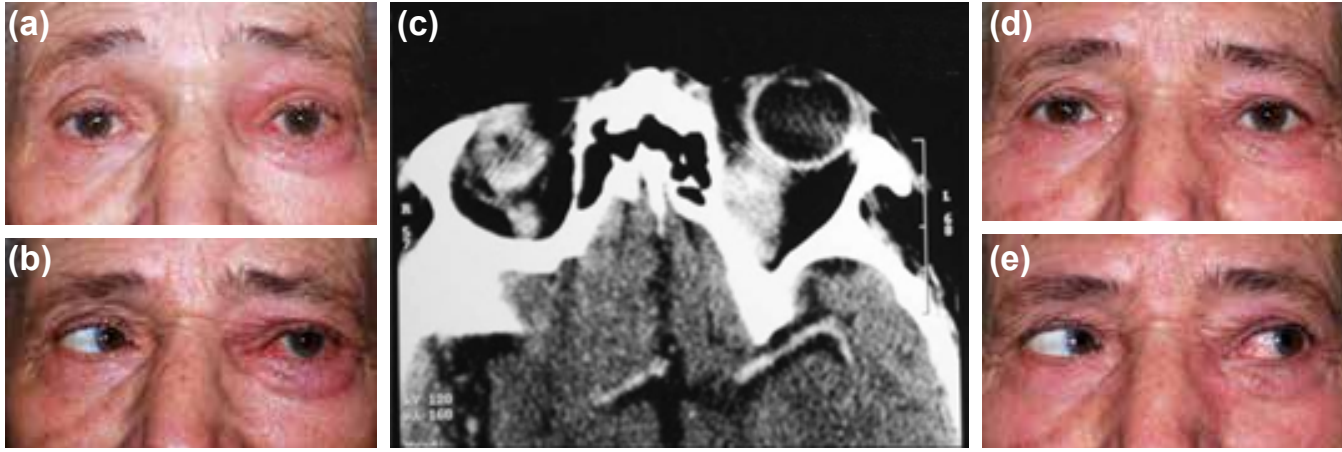

Figure 6. (a, b) Patient who presented with recurrent cellulitis and lateral gaze limitation had history of plant matter injury 1 year prior. (c) Lesion was hyperdense in contrastenhanced CT images. (d, e) Extraocular movement and orbital symptoms recovered after $\mathrm{FB}$ removal.
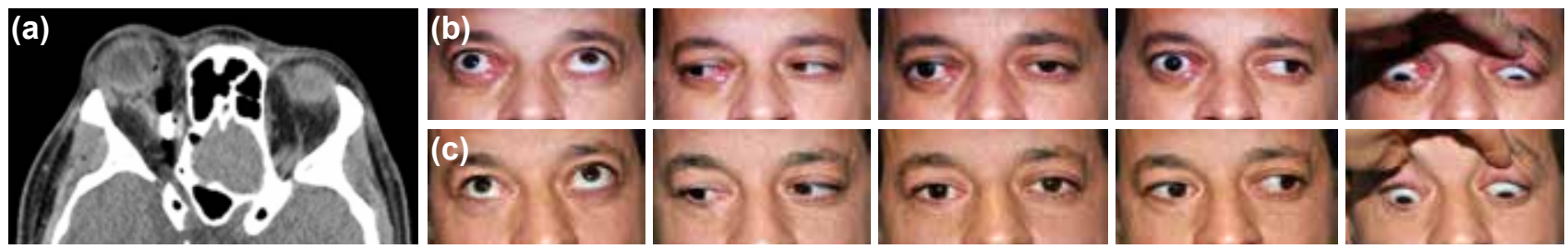

Figure 7. Patient in whom metallic FB in medial orbit was complicated with recurrent cellulitis, chorioretinopathy, and restrictive myopathy. (a) Appearance of FB in CT scan. (b, c) One year after surgery. Ocular motility and orbital symptoms improved after FB removal.

\section{DISCUSSION}

Detailed PubMed search yielded 5 studies in English literature published in the last 18 years, analyzing results of surgical removal of intraorbital FBs (Table I) ${ }^{[3-7]}$ Number of patients in these studies ranged from 19 to 53 (162 patients in total). Three studies ${ }^{[3,5,6]}$ included only patients with intraorbital FB who underwent surgery for FB removal and excluded patients who were not operated on, as in present study. Two studies $^{[4,5]}$ reflected the experience of only I medical center, while the others combined patients seen at multiple locations. Three studies ${ }^{[3,4,6]}$ included only metallic or organic FBs, while the other $2^{[5,7]}$ included all types of foreign material.

As in previous studies, most patients with intraorbital FB (54\%) in present study were young men of working age (Table I). In current study, $79 \%$ of intraorbital FBs were inorganic, and $54 \%$ were metallic. Those rates were $81 \%$ and $66 \%$, and 67 and $55 \%$ in earlier compatible studies. ${ }^{[5,7]}$ Rate of globe perforation ranged from $0 \%$ to $20 \%$ in previous studies, and was $8 \%$ in present study. ${ }^{[3-7]}$ As may be expected, this rate was much higher (44\% and $20 \%$ ) in studies that included patients with retained intraorbital FBs. ${ }^{[1,7]}$
The essential consideration in deciding to surgically remove intraorbital FBs is potential complications of leaving FB in place and of removal. Due to associated high risk of orbital cellulitis, all organic FBs should be removed. In present study, 2 patients who had organic FBs retained in orbit for about I year, presented with recurrent cellulitis or cutaneous fistula, and restrictive myopathy. In I of these, despite history of penetration of fresh tree branch in medial orbit, only a few, small, brown-black, fragile FBs in extensive scar tissue were found during surgery, and removal of these bits of matter resulted in resolution of all inflammatory symptoms and restrictive myopathy (Fig. 6). In the other patient, there was treated wood extending to apex in inferior orbit, and during removal, FB spontaneously divided into two pieces (Fig.l).

In current study, in addition to cases with organic FBs, 2 patients with metallic FBs had cellulitis. Both patients had large FBs in posterior medial orbit that penetrated the ethmoid sinuses, and lacrimal sac was injured in I patient. Metallic intraorbital FBs that disturb the isolation of lacrimal sac and paranasal sinuses may be complicated by infection. 
Table I. Several demographic and clinical characteristics of patients with intraorbital foreign bodies as reported in studies

\begin{tabular}{|c|c|c|c|c|c|c|c|}
\hline Study & $\begin{array}{l}\text { Patient } \\
(n=)\end{array}$ & $\begin{array}{c}\text { Mean age } \\
(y r)\end{array}$ & $\begin{array}{c}\text { Male patient } \\
(\%)\end{array}$ & $\begin{array}{l}\text { Early admission } \\
(\%)^{*}\end{array}$ & $\begin{array}{c}\text { Inorganic - } \\
\text { Organic FB (\%) }\end{array}$ & $\begin{array}{c}\text { Eye perforation } \\
(\%)\end{array}$ & $\begin{array}{c}\text { Orbital cellulitis } \\
\text { (\%) }\end{array}$ \\
\hline Finkelstein, 1996 & 27 & - & 93 & - & $100-0$ & 7 & - \\
\hline Nasr, 1998 & 19 & 15 & 79 & 26 & $0-100$ & 5 & 58 \\
\hline Fulcher, 2002 & 40 & 25 & 88 & 75 & $67.5-32.5$ & 20 & 25 \\
\hline Shelsta, 2010 & 23 & 22 & 96 & 43 & $0-100$ & 0 & - \\
\hline Callahan, 2013 & 53 & 37 & 89 & 72 & $81-15$ & 0 & 4 \\
\hline Present study, 2015 & 24 & 28 & 83 & 42 & $77-22$ & 9 & 18 \\
\hline
\end{tabular}

"Early admission was within 48 hours. FB: Foreign body.

Radiological examination of intraorbital FBs has been discussed elsewhere in detail. ${ }^{[3,5,8]}$ In brief, metallic FB can be easily detected with plain radiography or $\mathrm{CT}$, but organic $\mathrm{FB}$ may not be easily observed; MRI can provide more detailed

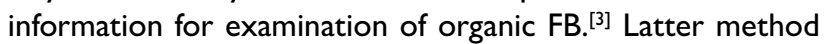
is contraindicated in cases of metallic FB.

Although most metals are inert, some such as iron, copper, and lead may cause serious complications. Location and size of metallic FB is important, as well as chemical structure. Small, inert, and deeply seated metallic objects are usually managed conservatively. ${ }^{[1,5]}$ However, ferromagnetic FBs left in orbit may prevent patients from undergoing MRI in future. Even though these materials can remain harmless for years, they can cause serious ocular injuries when exposed to strong magnetic forces. ${ }^{[7,9]}$ Unfortunately, imaging methods cannot differentiate metallurgical and magnetic properties of metallic FBs. One study found that most metallic intraorbital FBs were found to contain steel, and therefore be ferromagnetic. ${ }^{[7]}$

Gunshot injuries usually lead to severe ocular perforation and permanent visual loss; most patients require removal of the eye after primary repair. ${ }^{[I]}$ However, at time of primary repair, excessive surgical manipulation to remove FB in deep orbit should be avoided. Bullets and pellets are most commonly made with lead core and thin coating alloy (nickel, copper or antimony). ${ }^{[10]}$ Lead does not have magnetic properties, but may cause toxicity due to absorption in the body. Ho et al. ${ }^{[]}$observed no progressive ocular complication during follow-up period (range: 6 months-68 years; median: 2 years) in $95 \%$ of 43 patients with retained bullet or pellet in orbit. A study published in 1988 reported serum lead levels in normal limits $(350 \mu \mathrm{g} / \mathrm{L})$ in II patients with retained intraorbital pellet. ${ }^{[I]}$ However, recent, well-designed studies have reported elevated blood lead levels in patients with retained lead pellets compared to matched controls. ${ }^{[2-15]} \mathrm{Bul}-$ let fragmentation, multiple bullets, bone fracture, lodgment of bullet near bone or joint, and increased patient age are significant factors associated with high lead levels. ${ }^{[15]}$ Most symptoms of lead toxicity (plumbism) are nonspecific, and diagnosis is missed or delayed in many instances. ${ }^{[1,16-18]} \mathrm{Pa}-$ tients with retained lead pellets should be considered at risk for lead poisoning and follow-up should continue on regular basis. ${ }^{\left[{ }^{I I}\right]}$ Bullet or pellet fragments, in absence of intracranial extension, can be easily removed during enucleation or evisceration.

For gunshot injuries in which eyeball remains intact, removal of FB may be appropriate if it causes ocular morbidity such as restrictive myopathy, cellulitis, or optic neuropathy. In present study, removal of a BB gun pellet and repair of lateral rectus muscle and lateral orbital wall resulted in remarkable improvement in I patient (Fig. 4, 5). If FB is associated with large lacrimal sac laceration, performing external dacryocystorhinostomy during FB removal may obviate need for second, lacrimal surgery.

Surgical approach for FB removal is determined based on size and location of FB in orbit. FB can be accessed by exploring from entry site or through fistula pathway, if cutaneous fistula is present. ${ }^{[18]}$ It may be difficult to find small FBs encapsulated by fibrous scars in orbit. In such cases, it is helpful to use operation microscope and to follow scar tissue. Some authors use intraoperative fluoroscopy to locate radio-opaque FBs. ${ }^{[19]}$ Organic FBs degrade over time, therefore removal as a single piece may not be possible. These cases may require further dissection in soft tissue for complete removal of $\mathrm{FB}$.

Removal of small FBs located in orbital apex may result in serious complications. In current study, however, there was no such case, and removal of FBs in which distal end extended to orbital apex did not result in any complication. Postoperative visual loss has been reported in a few cases in previous studies (at rates of 2.5 to $4 \%$ ). ${ }^{[3-7]}$ Other complications, including formation of sterile granuloma and eyelid malposition, were also rare. ${ }^{[4,5]}$ Present study supports content that most intraorbital FBs can be removed safely with minimal complication rates using modern orbital surgical techniques.

Conflict of interest: None declared. 


\section{REFERENCES}

1. Ho VH, Wilson MW, Fleming JC, Haik BG. Retained intraorbital metallic foreign bodies. Ophthal Plast Reconstr Surg 2004;20:232-6.

2. Cooper W, Haik BG, Brazzo BG. Management of orbital foreign bodies. In: Nesi FA, Levine MR, Lisman RD, editors. Smith's Ophthalmic Plastic and Reconstructive Surgery. St. Louis: Mosby; 1998. p. 260-9.

3. Nasr AM, Haik BG, Fleming JC, Al-Hussain HM, Karcioglu ZA. Penetrating orbital injury with organic foreign bodies. Ophthalmology 1999;106:523-32. Crossref

4. Finkelstein M, Legmann A, Rubin PA. Projectile metallic foreign bodies in the orbit: a retrospective study of epidemiologic factors, management, and outcomes. Ophthalmology 1997;104:96-103. Crossref

5. Callahan $A B$, Yoon MK. Intraorbital foreign bodies: retrospective chart review and review of literature. Int Ophthalmol Clin 2013;53:157-65.

6. Shelsta HN, Bilyk JR, Rubin PA, Penne RB, Carrasco JR. Wooden intraorbital foreign body injuries: clinical characteristics and outcomes of 23 patients. Ophthal Plast Reconstr Surg 2010;26:238-44. Crossref

7. Fulcher TP, McNab AA, Sullivan TJ. Clinical features and management of intraorbital foreign bodies. Ophthalmology 2002;109:494-500. Crossref

8. Glatt HJ, Custer PL, Barrett L, Sartor K. Magnetic resonance imaging and computed tomography in a model of wooden foreign bodies in the orbit. Ophthal Plast Reconstr Surg 1990;6:108-14. Crossref

9. McNab AA, Satchi K. Orbital foreign bodies and penetrating orbital injuries. In: Black EH, Nesi FA, Calvano CJ, Gladstone GJ, Levine MR, editors. Smith and Nesi's Ophthalmic Plastic and Reconstructive Surgery. 3rd ed. New York: Springer; 2012. p. 297-307. Crossref
10. Wallace JS. Projectiles. In: Chemical Analysis of Firearms, Ammunition, and Gunshot Residue. Boca Raton, FL, USA: CRC Press, Taylor\&Francis Group; 2008. p. 67-90. Crossref

11. Jacobs NA, Morgan LH. On the management of retained airgun pellets: a survey of 11 orbital cases. Br J Ophthalmol 1988;72:97-100. Crossref

12. Moazeni M, Mohammad Alibeigi F, Sayadi M, Poorya Mofrad E, Kheiri S, Darvishi M. The Serum Lead level in Patients With Retained Lead Pellets. Arch Trauma Res 2014;3:18950. Crossref

13. Nguyen A, Schaider JJ, Manzanares M, Hanaki R, Rydman RJ, Bokhari F. Elevation of blood lead levels in emergency department patients with extra-articular retained missiles. J Trauma 2005;58:289-99. Crossref

14. Farrell SE, Vandevander P, Schoffstall JM, Lee DC. Blood lead levels in emergency department patients with retained lead bullets and shrapnel. Acad Emerg Med 1999;6:208-12. Crossref

15. McQuirter JL, Rothenberg SJ, Dinkins GA, Kondrashov V, Manalo M, Todd AC. Change in blood lead concentration up to 1 year after a gunshot wound with a retained bullet. Am J Epidemiol 2004;159:683-92.

16. Schaumberg DA, Mendes F, Balaram M, Dana MR, Sparrow D, Hu $\mathrm{H}$. Accumulated lead exposure and risk of age-related cataract in men. JAMA 2004;292:2750-4. Crossref

17. Magos L. Lead poisoning from retained lead projectiles. A critical review of case reports. Hum Exp Toxicol 1994;13:735-42. Crossref

18. Orcutt JC. Orbital foreign bodies. In: Linberg JV, editor. Oculoplastic and Orbital Emergencies. Norwalk: Appleton\&Lange; 1990. p. 183-97.

19. Cho RI, Kahana A, Patel B, Sivak-Callcott J, Buerger DE, Durairaj VD, et al. Intraoperative fluoroscopy-guided removal of orbital foreign bodies. Ophthal Plast Reconstr Surg 2009;25:215-8. Crossref

\section{ORIJINAL ÇALIŞMA - ÖZET}

\section{İntraorbital yabancı cisimler: Klinik özellikleri ve cerrahi çıkartım sonuçları Dr. Ayşe Dolar Bilge, Dr. Hakan Yıımaz, Dr. Bülent Yazıcı, Dr. Faisal Naqadan}

Uludağ Üniversitesi Tıp Fakültesi, Göz Hastalıkları Anabilim Dalı, Bursa

AMAÇ: Orbitaiçi yabancı cisim nedeniyle ameliyat edilen hastaların klinik özellikleri ve tedavi sonuçları değerlendirildi. GEREÇ VE YÖNTEM: On yıllık bir dönemde orbitaiçi yabancı cisim nedeniyle ameliyat edilen 24 hastanın tıbbi dosyası gözden geçirildi. BULGULAR: Yirmi hasta (\%83) erkek, dört hasta (\% I7) kadındı (ortalama yaş, 28 yıl; veri aralığı: 4-69 yıl). On hasta (\%42) travmayı izleyen 48 saat içinde, yedi hasta (\%29) üç gün-bir ay içinde ve yedi hasta (\%29) bir aydan sonra başvurdu. Yabancı cisim 19 hastada (\%79) inorganik, beş hastada (\%2I) organikti. Yabancı cisme eşlik eden majör oküler morbiditeler, orbital sellülit $(n=5)$, travmatik optik nöropati $(n=3)$, göz perforasyonu ( $n=2)$ ve rektus kası kopmasıydı $(n=2)$. Tüm hastalarda yabancı cisim tam olarak çıkartıldı. Ortalama izlem süresi 26 aydı (veri aralığı: I ay-ı0 yıl).

TARTIŞMA: Orbitaiçi yabancı cisimler sıklıkla inorganik ve metaliktir; genç erkeklerde daha sık görülür. Orbital sellülit organik yabancı cisimler için tipik sayılmakla birlikte, lakrimal kese ve paranazal sinüsleri perfore eden metalik yabancı cisimlere bağlı olarak da görülebilir. Orbitaiçi yabancı cisimler, modern orbita cerrahisi yöntemleriyle güvenli bir biçimde çıkartılabilir.

Anahtar sözcükler: Cerrahi tedavi; orbitaiçi yabancı cisim; orbitotomi.

Ulus Travma Acil Cerrahi Derg 2016;22(5):432-436 doi: 10.5505/tjtes.2016.20925 